\title{
Evaluation of sorghum (Sorghum bicolor (L.) Moench) varieties, for yield and yield components at Kako, Southern Ethiopia
}

\author{
Tekle Yoseph ${ }^{1, *}$, Zemach Sorsa ${ }^{2}$ \\ ${ }^{1}$ Southern Agricultural Research Institute, Jinka Agricultural Research Center, Department of Crop Science Research Process, Jinka, \\ Ethiopia \\ ${ }^{2}$ Department of Plant Sciences, Wolaita Sodo University, Wolaita Sodo, Ethiopia
}

\section{Email address:}

tganta@yahoo.com (T. Yoseph)

\section{To cite this article:}

Tekle Yoseph, Zemach Sorsa. Evaluation of Sorghum (Sorghum bicolor (L.) Moench) Varieties, for Yield and Yield Components at Kako, Southern Ethiopia. Journal of Plant Sciences. Vol. 2, No. 4, 2014, pp. 129-133. doi: 10.11648/j.jps.20140204.12

\begin{abstract}
A field experiment involving seven improved sorghum [Sorghum bicolor (L.) Moench] varieties and one local check was carried out at Kako farmers' training center during the 2006 main cropping season to identify the best performing variety to the lowlands of South Omo Zone. The sorghum varieties included in the field experiment were seven improved (Seredo, Meko-1, 76TI\#23, Gambella 1107, Teshale, Gubiye, Abshir) and a local check. The experimental design was a randomized complete block design (RCBD) with three replications. Phenological and growth parameters such as yield and yield components, total biomass and harvest index were studied. The result showed that all phenological and growth parameters were significantly affected by variety except number of tillers and panicle length per plant. There was a proportional increment on the number of tillers per plant observed for the improved sorghum varieties over the local check. Grain yield, total biomass, 1000 seeds weight and harvest index were significantly affected by variety. Grain yield advantages of $74.26 \%, 64.96 \%$ and $58.06 \%$, were obtained from the improved sorghum varieties Teshale, Meko-1 and Gambella 1107, respectively over the local check. The highest grain yields of $\left(3.3667 \mathrm{t} \mathrm{ha}^{-1}\right)$ and $\left(2.4733 \mathrm{t} \mathrm{ha}^{-1}\right) \mathrm{were}$ recorded for the varieties Teshale and Meko-1, respectively. Therefore, it can be concluded that use of the improved sorghum varieties such as Teshale or Meko-1 is advisable and could be appropriate for sorghum production in the test area even though further testing is required to put the recommendation on a strong basis.
\end{abstract}

Keywords: Growth Parameters, Phenological Parameters, Sorghum Variety, Yield Components, Yield

\section{Introduction}

Sorghum [Sorghum bicolor (L.) Moench] is a viable food grain for many of the World's most food insecure people who live in marginal areas with poor and erratic rains and often poor soils [1] It is the fifth most important cereal crop in the world [2, 3]. Sorghum is cultivated in wide geographic areas in the Americas, Africa, Asia and the Pacific. It is the third important cereal (after rice and wheat) in India. It is the second major crop (after maize) across all agro ecologies in Africa. Sorghum is a major cereal crop in arid and semi-arid areas of the world. It is a staple crop of semiarid sub-Saharan Africa. In West Africa, farmers grow mainly guinea race landraces that are especially adapted to the harsh and unpredictable conditions of the sub-Sahelian zone [4]. In West Africa, especially in Burkina Faso, it is the staple crop and produced in low-input cropping systems [5]. Sorghum is a major food and nutritional security crop to more than 100 million people in Eastern horn of Africa, owing to its resilience to drought and other production constrains [6]. It is a staple food crop on which the lives of millions of poor Ethiopians depend. It has tremendous uses for the Ethiopian farmer and no part of this plant is ignored [7]. Besides being a major source of staple food for humans, it serves as an important source of feed and fodder for animals. Sorghum exhibits a wide geographic and climatic adaptation. It also requires less water than most cereals; hence it offers great potential for supplementing food and feed resources [8]. Sorghum grows in a wide range of agro ecologies most importantly in the moisture stressed parts where other crops can least survive and food insecurity is rampant [7]. 
Sorghum is one of the leading traditional food crops in Ethiopia comprising $15-20 \%$ of the total cereal production in the country $[9,10]$. It is the fourth most important food crop after maize, wheat and tef and also the most important in the drier parts of the country [1]. Ethiopian national average yield was $1.302 \mathrm{t} \mathrm{ha}^{-1}$ [11]; whereas, the world average yield was $2.3 \mathrm{t} \mathrm{ha}^{-1}[12]$. The low productivity of sorghum in Ethiopia could be attributed to biotic and edaphic factors affecting directly and indirectly sorghum production.

Sorghum is becoming a high potential crop in Southern region in general and South Omo Zone in particular. It is the dominant crop in the low land areas of Southern Ethiopia, especially South Omo Zone and Segen people Zone. Sorghum production is increasing in South Omo Zone of Southern Ethiopia, but there are a number of production constraints with this crop. Even though, the crop is important in the target area, a number of factors constrained productivity of sorghum in the target areas. This is associated with the lack of improved varieties associated with edaphic and biotic factors that have been appreciated as one of the primary sources of lower sorghum production in the target areas. There had no trend of using improved of sorghum varieties in the in the existing production system, so that it was the bottle neck problem in the study area. Hence; there is need to introduce improved sorghum varieties to the target area is crucial for sorghum production and productivity. Therefore, this study is aimed at and initiated with the objective of selecting the best performing sorghum varieties to the target area.

\section{Materials and Methods}

\subsection{Description of the Study Area}

The experiment was conducted at Kako farmer's training center located at $036^{\circ} 40.259^{\prime}$ E longitude and $05^{\circ} 38.332^{\prime}$ $\mathrm{N}$ latitude and at an altitude of 1305 meters above sea level (masl). Geographically, Kako is situated in South Ethiopia at about $711 \mathrm{kms}$ from the capital Addis Ababa. The long term weather data of the area revealed that the mean annual rainfall of the area is $68.14 \mathrm{~mm}$ with a range of 32.59 to $115.96 \mathrm{~mm}$. The experiment was conducted during the main cropping season (February to June, 2006) under rain fed conditions.

\subsection{Treatments and Experimental Design}

The experiment was executed by using seven improved sorghum varieties and one local check. The field experiment was laid out in a randomized complete block design (RCBD) with three replications. Sorghum was sown on February 22, 2006 in eight rows per plot with spacing of $75 \mathrm{~cm}$ between rows and $15 \mathrm{~cm}$ between plants within a row with gross plot area of $30 \mathrm{~m}^{2}$.

\subsection{Data Collection}

\subsubsection{Phenological Parameters}

Phenological parameters such as days to emergence, days to heading and days to maturity were recorded. Days to emergence was recorded when $50 \%$ the plants per plot emerged while days to heading was recorded by counting the number of days after emergence when $50 \%$ of the plants per plot had the first open flower. Days to maturity were recorded when $90 \%$ of heads per plot.

\subsubsection{Growth Parameters}

At mid flowering stages ten plants from each of the plots were selected randomly and uprooted carefully to determine crop growth parameters such as plant height and number of tillers.

\subsubsection{Grain Yield, Yield Components, Total Biomass and Harvest Index}

Four central rows $\left(5 \mathrm{~m} \times 3 \mathrm{~m}=15 \mathrm{~m}^{2}\right)$ were harvested for determination of grain yield. Grain yield was adjusted to $12.5 \%$ moisture content. Ten plants were randomly selected from the four central rows to determine yield and yield components, which consisted of number of tillers per plant and thousand seeds weight. Seed weight was determined by taking a random sample of 1000 seeds and adjusted them to $12.5 \%$ moisture content. Total biomass yield was measured from the four middle rows when the plant reached harvest maturity. Harvest index was calculated as the ratio of seed yield to total above ground biomass yield.

\subsection{Statistical Analysis}

Analysis of variance was performed using the GLM procedure of SAS Statistical Software Version 9.1 [13]. Effects were considered significant in all statistical calculations if the P-values were $\leq 0.05$. Means were separated using Fisher's Least Significant Difference (LSD) test.

\section{Results and Discussion}

According to the result of analysis of variance for mean squares, days to heading was significantly $(\mathrm{P}<0.001)$ influenced by varieties whereas; days to maturity and plant height were significantly $(\mathrm{P}<0.001)$ affected by varieties (Table 1). Similar result was reported by the previous work [14]. On the other hand; number of tillers per plant and panicle lengths of sorghum was not significantly affected by varieties (Table 1). Though no significant variations observed for tiller number per plant, but there was relatively highest tiller number per plant recorded for the improved varieties Teshale, Abshir and Seredo, respectively than the local check (Table 2). The maximum number of tillers per plant (3), (2.766) and (2.667) were recorded for the improved varieties Teshale, Abshir, Seredo, respectively. While; the minimum number of tillers per plant of (2.333) was noted for the local check (Table 2). In this result it was 
noted that, the improved sorghum varieties were the capacity to produce more tillers than the local check.

The result of analysis of variance for mean squares revealed that there was a significant variation observed among the sorghum varieties for grain yield (Table 3 ). This finding is in line with the findings of previous work [14]. Total biomass weight of sorghum was significantly $(\mathrm{P}<$ 0.01 ) affected by varieties. Also 1000 seeds weight was significantly $(\mathrm{P}<0.001)$ influenced by varieties (Table 3 ). The result also showed that there was a significant variation noted among the sorghum varieties for harvest index (Table $3)$. The maximum 1000 seeds weights of (28.7 gm), $(27.667 \mathrm{gm})$ and $(27.000 \mathrm{gm})$ were recorded for the improved sorghum varieties Meko-1, Teshale and Gambella 1107 , respectively and the minimum 1000 seeds weight of (20.333 gm) was recorded for the local check (Table 4). The maximum grain yields of $\left(3.3667 \mathrm{tha}^{-1}\right),\left(2.4733 \mathrm{t} \mathrm{ha}^{-1}\right)$ and $\left(2.0667 \mathrm{t} \mathrm{ha}^{-1}\right)$ were recorded for the sorghum varieties Teshale Meko-1 and Gambella 1107, respectively and the minimum grain yield of $\left(0.8667 \mathrm{t} \mathrm{ha}^{-1}\right)$ was noted for the local check (Table 4). Grain yield advantages of $74.26 \%$,
$64.96 \%$ and $58.06 \%$ were obtained from the improved sorghum varieties Teshale and Meko-1, respectively over the local check in this study. The grain yield advantage obtained from the improved sorghum varieties is related with the increased number yield attributing parameters such as 1000 seeds weight and productive tillers. From the above findings it could be suggested that use of the improved sorghum varieties had brought a proportional yield increment than the local check. The maximum biomass yields of $\left(27.333 \mathrm{tha}^{-1}\right),\left(24.000 \mathrm{t} \mathrm{ha}^{-1}\right)$ and $\left(22.333 \mathrm{t} \mathrm{ha}^{-1}\right)$ were noted from the improved sorghum varieties Meko-1, Gambella 1107 and Gubiye, respectively and minimum biomass yield of $\left(9.00 \mathrm{t} \mathrm{ha}^{-1}\right)$ was recorded from the local check (Table 4). There was also biomass yield advantages of $67.07 \%$ and $62.5 \%$ and $59.7 \%$ were obtained from the improved sorghum varieties Meko-1, Gambella 1107 and Gubiye, respectively over the local check. The biomass yield advantage observed in this study might be attributed by the enhanced tiller number from the improved sorghum varieties than the local check.

Table 1. Mean Square Values for Crop Phenology and Growth Parameters of Sorghum at Kako, in 2006.

\begin{tabular}{lllllll}
\hline Source & DF & Days to heading & Days to maturity & Tiller number plant ${ }^{-1}$ & Plant height (cm) $^{\text {PanicleLength (cm) }}$ \\
\hline Replication (R) & 2 & $0.5417 \mathrm{~ns}$ & $26.5417 \mathrm{~ns}$ & $1.7917^{*}$ & $59.95^{*}$ & $.1 .98 \mathrm{~ns}$ \\
Variety (VAR.) & 7 & $313.1191^{* * *}$ & $416.6131^{* * *}$ & $0.5476 \mathrm{~ns}$ & $2379.73^{* * *}$ & $5.98 \mathrm{~ns}$ \\
Error & 14 & 23.0655 & 12.9702 & 0.4583 & 13.27 \\
\hline
\end{tabular}

$*, * *$ and $* * *$ indicate significance at $\mathrm{P}<0.05, \mathrm{P}<0.01$ and $\mathrm{P}<0.001$, respectively and 'ns' indicate non significant

Table 2. Crop Phenology and Growth Parameters of Sorghum as Affected By Variety at Kako, in 2006

\begin{tabular}{|c|c|c|c|c|c|}
\hline Treatments & Days to heading & Days to maturity & Tiller number $\left(\right.$ plant $\left.^{-1}\right)$ & Plant height (cm) & Panicle Length $(\mathrm{cm})$ \\
\hline $\begin{array}{l}\text { VARIETIES } \\
\text { SEREDO }\end{array}$ & $75.667 \mathrm{c}$ & $108.00 \mathrm{~d}$ & $2.667 \mathrm{a}$ & $138.867 d$ & $20.600 \mathrm{a}$ \\
\hline MEKO-1 & $83.667 b c$ & $104.667 d$ & $2.000 \mathrm{a}$ & $164.333 \mathrm{c}$ & $19.000 \mathrm{a}$ \\
\hline 76TI \# 23 & $78.00 \mathrm{bc}$ & $108.00 \mathrm{~d}$ & $2.000 \mathrm{a}$ & $131.133 \mathrm{e}$ & $18.000 \mathrm{a}$ \\
\hline GAMBELLA 1107 & $85.00 \mathrm{~b}$ & $115.667 \mathrm{bc}$ & $2.333 \mathrm{a}$ & $189.333 \mathrm{a}$ & $21.867 \mathrm{a}$ \\
\hline TESHALE & $75.333 c$ & $110.00 \mathrm{~cd}$ & $3.000 \mathrm{a}$ & $175.000 \mathrm{~b}$ & $18.467 \mathrm{a}$ \\
\hline GUBIYE & $82.667 \mathrm{bc}$ & $118.667 \mathrm{~b}$ & $2.000 \mathrm{a}$ & $118.867 \mathrm{f}$ & $20.467 \mathrm{a}$ \\
\hline ABSHIR & $77.667 \mathrm{bc}$ & $115.333 \mathrm{bc}$ & $2.766 a$ & $136.267 \mathrm{de}$ & $17.867 \mathrm{a}$ \\
\hline LOCAL CHECK & $106.667 \mathrm{a}$ & $142.000 \mathrm{a}$ & $2.333 \mathrm{a}$ & $192.533 \mathrm{a}$ & $18.867 \mathrm{a}$ \\
\hline LSD 0.05 & 8.41 & 6.30 & NS & 6.38 & NS \\
\hline $\mathrm{CV}(\%)$ & 5.76 & 3.12 & 28.01 & 2.33 & 16.00 \\
\hline
\end{tabular}

Note: Means with the same letters within the columns are not significantly different at $\mathrm{P}<0.05$.

Table 3. Mean Square Values for Yield and Yield Components and Total Biomass in Sorghum at Kako, in 2006

\begin{tabular}{|c|c|c|c|c|c|}
\hline Source & DF & Grain Yield $\left(\mathrm{t} \mathrm{ha}^{-1}\right)$ & 1000 Seeds Wt (gm) & Total Biomass $\left(\mathrm{t} \mathrm{ha}^{-1}\right)$ & Harvest Index \\
\hline Replication (R) & 2 & $0.2391 \mathrm{~ns}$ & $1.1754 *$ & $34.125 \mathrm{~ns}$ & $0.00189 \mathrm{~ns}$ \\
\hline Variety (Var.) & 7 & $1.6274 * * *$ & $24.2742 * * *$ & $109.5952 * *$ & $0.01309 *$ \\
\hline Error & 14 & 0.07948 & 0.3135 & 20.2202 & 0.00448 \\
\hline
\end{tabular}

$*, * *$ and $* * *$ indicate significance at $\mathrm{P}<0.05, \mathrm{P}<0.01$ and $\mathrm{P}<0.001$, respectively and 'ns' indicate non significant 
Table 4. Yield and Yield Components of Sorghum as Affected By Variety at Kako, in 2006.

\begin{tabular}{lllll}
\hline Treatments & Grain Yield $\left(\mathbf{t ~ h a}^{-1}\right)$ & $\mathbf{1 0 0 0}$ seeds Weight $(\mathbf{g m})$ & Total Biomass Weight $\left(\mathbf{t ~ h a}^{-1}\right)$ & Harvest Index \\
\hline VARIETIES & $1.800 \mathrm{c}$ & $24.00 \mathrm{c}$ & $18.667 \mathrm{bcd}$ & $0.14234 \mathrm{abc}$ \\
SEREDO & $2.4733 \mathrm{~b}$ & $28.70 \mathrm{a}$ & $27.333 \mathrm{a}$ & $0.06851 \mathrm{c}$ \\
MEKO-1 & $1.5333 \mathrm{c}$ & $22.00 \mathrm{~d}$ & $16.000 \mathrm{bcde}$ & $0.14949 \mathrm{abc}$ \\
76TI \# 23 & $2.0667 \mathrm{~b}$ & $27.000 \mathrm{~b}$ & $24.000 \mathrm{ab}$ & $0.08611 \mathrm{bc}$ \\
GAMBELLA 1107 & $3.3667 \mathrm{a}$ & $27.667 \mathrm{~b}$ & $15.333 \mathrm{cde}$ & $0.22065 \mathrm{a}$ \\
TESHALE & $1.6540 \mathrm{c}$ & $24.667 \mathrm{c}$ & $0.20477 \mathrm{ab}$ \\
GUBIYE & $1.7333 \mathrm{c}$ & $25.000 \mathrm{c}$ & $13.333 \mathrm{de}$ & $0.16032 \mathrm{ab}$ \\
ABSHIR & $0.8667 \mathrm{~d}$ & $20.333 \mathrm{e}$ & $0.03175 \mathrm{c}$ \\
LOCAL CHECK & 0.4937 & 0.9805 & $9.000 \mathrm{e}$ & 0.1173 \\
LSD 0.05 & 14.55 & 2.24 & 7.8747 & 7.09 \\
CV (\%) & & 24.63 & \\
\hline
\end{tabular}

Note: Means with the same letters within the columns are not significantly different at $\mathrm{P}<0.05$.

\section{Summary and Conclusion}

Using improved varieties of sorghum could make an important contribution to increase agricultural production and productivity in areas like Kako where there is low practice of using improved technologies such as improved crop varieties. To this end, use of improved sorghum technologies such as improved varieties could be one of the alternatives to improve productivity by small farmers. However, the use of improved sorghum varieties is not yet studied in the area. Thus, this research work is initiated to investigate the impact of including improved sorghum varieties on the existing production system is of paramount important.

Study on sorghum variety was conducted at Kako under rain fed conditions in 2006. The objective of the study was to determine the best performing sorghum variety that will improve sorghum production and productivity in the target area. The experiment was carried out using the randomized complete block design (RCBD) with three replications at Kako in 2006. During the field implementation, seven improved sorghum varieties and one local check were used. According to the results of analysis of variance, all the phenological and growth parameters were significantly affected by varieties except number of tillers and panicle length per plant. The maximum number of tillers per plant was noted for the improved sorghum varieties. All the yield and yield components studied in this experiment such as grain yield, 1000 seeds weight, and total biomass weight and harvest index were significantly affected by varieties. The highest grain yields of $\left(3.3667 \mathrm{tha}^{-1}\right)$ and $\left(2.4733 \mathrm{t} \mathrm{ha}^{-1}\right)$ were recorded for the sorghum varieties Teshale and Meko1 , respectively. Therefore, it can be concluded that use of the improved sorghum varieties such as Teshale or Meko-1 is advisable and could be appropriate for sorghum production in the test area even though further testing is required to put the recommendation on a strong basis.

\section{References}

[1] AATF [African Agricultural Technology Foundation]. 2011. Feasibility Study on Striga Control in Sorghum Nirobi, African Agricultural Technology Foundation. ISBN 9966775-12-9

[2] FAO. 2005. FAO STAT statistical data base for Agriculture

[3] FAO. (1998). Seed Policy And Programmes For Sub Saharan Africa : Proceedings Of The Regional Technical Meetings On Seed Policy And Programmes For Sub Saharan Africa, Abidjan, Cote Devoire 23-27 November, 1998, Rome, Italy: The FAO

[4] Lacy, S.M., Cleveland, D.A., Soleri, D., 2006. Farmer choice of sorghum varieties in southern Mali. Hum. Ecol. 34, 331-353.

[5] Kirsten vom Brockea, Gilles Trouche, Eva Weltzien, Clarisse P. Barro-Kondombo, Eric Gozé, Jacques Chantereau. 2010. Participatory variety development for sorghum in Burkina Faso: Farmers' selection and farmers' criteria. Field Crops Research 119 (2010) 183-194

[6] Gudu S, E.O. Ouma, A.O. Onkware, E.J. Too, B.A. Were, J.O. Ochuodho, C.O. Othieno, J.R. .Okalebo, J. Agalo and S.M. 2013. Preliminary Participatory On-farm Sorghum Variety Selection for Tolerance to drought, Soil Acidity and Striga in Western Kenya. Maina Moi University, Kenya First Bio-Innovate Regional Scientific Conference United Nations Conference Centre (UNCC-ECA) Addis Ababa, Ethiopia.

[7] Adugna Asfaw. 2007. The role of introduced sorghum and millets in Ethiopian agriculture Melkassa Agricultural Research Center, Nazareth, Ethiopia. SAT eJournal ejournal.icrisat.org Volume 3 Issue 1

[8] KARI (Kenya Agricultural Research Institute). 2000. Proceedings of the 7th KARI Biennial Scientific Conference.

[9] Central Statistics Authority (CSA). 2000. Agricultural sample survey 1999/2000. Report on area and production for major crops (private peasant holdings, main season). Statistical Bulletin No. 227. Addis Ababa, Ethiopia. 
[10] Wortmann, C.S., Martha Mamo,Girma Abebe, Kaizzi, K., Mburu, C., Letayo, E \& Xerinda, S.2006. An atlas of sorghum production in eastern Africa. http://intsormil.org. Accessed 15 June 2010.

[11] CSA (Central Statistical Authority) (Federal Democratic Republic of Ethiopia), 2005. Agricultural Sample Survey. Volume IV. Report on land utilization.

[12] Benti, T. 1993. The need and objective of the first national maize workshop. In: T. Benti and J. Ranson (eds.), Proceedings of the first national maize workshop of Ethiopia.
5-7 May 1992, IAR/CIMMYT, Addis Abeba, Ethiopia. 1$5 \mathrm{pp}$.

[13] SAS (2007) Statistical Analysis Systems SAS/STAT user's guide Version 9.1 Cary NC: SAS Institute Inc. USA

[14] Hussain Nazir, Mohammad Safdar Baloch, Muhammad Yousaf Muhammad Naeem,Abdul Aziz Khakwani and Irshad Begum. 2011. Performance of Sorghum Varieties in Potohar Region. Gomal University Journal of Research, 27(2). December 2011. 